\title{
EKSISTENSI HAKIM PERDAMAIAN DESA DALAM PENYELESAIAN SENGKETA DI PENGADILAN NEGERI
}

\author{
Efa Laela Fakhriah \\ Fakultas Hukum Universitas Padjadjaran \\ E-mail: efalaela@yahoo.co.id
}

\begin{abstract}
ABSTRAK. Berdasarkan penjelasan Pasal 135a HIR/161a RBG, bahwa dalam perkara perdata tertentu keputusan hakim desa itu demikian penting sehingga apabila penggugat belum menyelesaikan perkara tersebut ke hakim desa padahal hakim memandang perlu untuk diperiksa lebih dahulu oleh hakim desa sebelum diajukan ke pengadilan, maka pemeriksaan perkara diundur untuk memberikan kesempatan pemeriksaan oleh hakim desa. Apabila yang bersangkutan ternyata tidak membawa perkara itu kepada hakim desa setelah diperintahkan oleh Ketua Pengadilan Negeri, maka akan berakibat hukum pemeriksaan perkara itu tidak akan dilanjutkan.Walaupun demikian,dalam praktik penyelesaian sengketa perdata dari hasil penelitian di Pengadilan Negeri Bandung diperoleh data bahwa ketentuan Pasal 135a HIR/161a RBg tidak pernah diterapkan setidaknya dalam masa tugas nara sumber, hal ini disebabkan hakim tidak memperhatikan keberadaan pasal tersebut. Sementara di Pengadilan Negeri Padang, Pengadilan Negeri Sampang Madura, dan Pengadilan Negeri Denpasar Bali, meskipun hakim mengetahui tentang keberadaan putusan hakim perdamaian desa sebagaimana diatur dalam pasal tersebut, namun belum pernah menerapkannya dalam praktik penyelesaian sengketa perdata.
\end{abstract}

Kata kunci: hakim desa, penyelesaian sengketa, pengadilan

\section{THE EXISTENCE OF JUSTICE OF THE PEACE VILLAGE IN RESOLVING DISPUTES IN THE DISTRICT COURT}

\begin{abstract}
Based on the explanation of Article 135a HIR/161a RBg, that in certain civil cases the village judge's decission so important, so that if the claimant has not completed the case to the judge village, even though judge deems it necessary to be examined in advance by the judge village before trial, the case investigation is postponed to allow inspection by the judge village. If the claimant did not bring the matter to the judge village after a judge ordered by the Chairman of the Court, it will result in the law that the examination of the case will not proceed. However, in practice settlement of civil disputes of research in Bandung District Court data showed that the provisions of Article 135A HIR/161 a RBg never be applied at least in a period of resource assignment, it is because the judge did not pay attention to the existence of such article. While at the Padang District Court, Sampang Madura District Court and Bali Denpasr District Court, although the judge know about the presence of the judge village peace decision as stipulated in that article, but never put them into practice settlement of civil disputes
\end{abstract}

Key words: judge village, dispute resolution, cour

\section{PENDAHULUAN}

Di mana ada hukum di situ ada masyarakat (ibi ius ubi societas), demikian kita kenal bahwa hukum itu ada dalam masyarakat yang merupakan kumpulan manusia sebagai mahluk sosial yang sepanjang hidupnya senantiasa memerlukan keberadaan manusia lainnya. Manusia tidak dapat bertahan hidup tanpa adanya manusia lainnya dengan kepentingannya masing-masing yang satu sama lain berbeda. Kepentingan manusia yang satu dengan lainnya senantiasa tidak sama, sehingga adakalanya perbedaan kepentingan tersebut dapat menimbulkan konflik. Konflik yang berkepanjangan dan tidak terselesaikan, dapat berkembang menjadi sengketa yang mau tidak mau harus diselesaikan guna menjaga keseimbangan dalam hidup bermasyarakat.

Penyelesaian sengketa, dalam hal ini sengketa perdata dapat dilakukan baik secara konvensional melalui pengadilan (litigasi) maupun melalui mekanisme penyelesaian sengketa alternatif di luar pengadilan (non litigasi). Prosedur penyelesaian sengketa perdata melalui pengadilan bersumber pada het Herzienne Indonesische Reglement (HIR) yang berlaku untuk wilayah hukum
Jawa dan Madura, dan Rechts Buitengewesten (RBg) untuk wilayah hukum luar Jawa dan Madura, sebagai hukum acara perdata positif.

Hukum acara yang mengatur tentang prosedur beracara ke pengadilan bersifat mengikat dan memaksa (tidak boleh disimpangi) bagi para pihak yang menerapkannya, dalam hal ini baik bagi para pihak pencari keadilan maupun bagi penegak hukum, dalam hal ini hakim dan kuasa hukum dari para pihak yang berperkara, lihat Sudikno 2006.

Pasal 135a (1) HIR mengatur mengenai keberadaan serta peran dan fungsi hakim desa dalam memutus persengketaan-persengketaan yang timbul diantara penduduk desa. "Hakim desa" yang dimaksud dalam pasal ini ialah suatu macam hakim atau pengadilan menurut hukum adat guna mendamaikan persengketaanpersengketaan, perselisihan-perselisihan dan pertikaianpertikaian yang timbul di antara penduduk desa, seperti pertikaian tentang pembagian air, mengenai pemakaian tanah, penggembalaan ternak dan segala sesuatu yang mengenai adat kebiasaan di desa dan peri kehidupan sehari-hari di dalam lingkungan desa itu. ${ }^{1}$

\footnotetext{
R. Tresna, Komentar HIR, Cetakan 13, Pradnya Paramita, Bandung, 1989, hlm 140
} 
Undang Undang Darurat Nomor 1 Tahun 1951 telah memutuskan untuk mencabut beberapa bentuk pengadilan ternasuk di dalamnya Pengadilan Adat, namun demikian dijelaskan lebih lanjut bahwa pencabutan keberlakuan pengadilan adat ini tidak mengurangi hak kekuasaan yang diberikan pada Hakim Perdamaian Desa sebagaimana diatur dalam Pasal 135a HIR. Dengan demikian pasal ini masih berlaku secara yuridis formal.

Dalam penjelasan atas Pasal 135a (1) HIR tersebut, dijelaskan bahwa ketentuan ini diadakan agar Pengadilan Negeri jika melanjutkan pemeriksaan atas perkara dimaksud, hakim mempunyai pegangan dan pandangan bagaimana hakim desa meniali perkara tersebut dari sudut hukum adat. Bahkan lebih lanjut dikatakan bahwa jika penggugat tidak membawa perkara dimaksud itu kepada hakim desa setelah diperintahkan oleh ketua Pengadilan Negeri, maka gugatannya tidak akan diteruskan.

Menurut ketentuan di atas, untuk sengketasengketa yang timbul karena perselisihan dan pertikaian di antara penduduk desa, seperti misalnya mengenai pertikaian tentang pembagian air, mengenai pemakaian tanah, penggembalaan ternak dan segala sesuatu yang mengenai adat kebiasaan di desa dan peri kehidupan sehari-hari di dalam lingkungan desa itu; harus diselesaikan dulu pada tingkat pengadilan desa melalui hakim desa yang berlandaskan pada penyelesaian secara damai dengan putusan hakim perdamaian desa. Apabila masih belum dapat diselesaikan secara tuntas, dapat diajukan ke Pengadilan Negeri untuk diperiksa kembali.

Kepentingan adanya putusan hakim perdamaian desa dalam proses pemeriksaan perkara di pengadilasn untuk kasus-kasus tertentu, dimaksudkan untuk menselaraskan pemikiran dan pertimbangan hukum hakim yang memeriksa perkara tersebut di Pengadilan Negeri dengan hakim desa yang telah memutus sebelumnya, sehingga pemeriksaan perkara dapat lebih cepat karena langsung terfokus pada pokok perkara melanjutkan hasil pemeriksaan hakim desa yang juga dijadikan pertimbangan hukum oleh hakim dalam memutus perkara dimaksud.

Pertanyaannya adalah bagaimana penerapan Pasal 135a HIR dalam praktiknya di pengadilan, apakah hakim secara konsisten melaksanakannya atau tidak. Untuk itu perlu dilakukan penelitian terhadap penerapan pasal tersebut di pengadilan, dengan membandingkan antara pengadilan di wilayah hukum yang sedikit pengaruh adatnya seperti Pengadilan Negeri Bandung dengan pengadilan-pengadilan di wilayah hukum yang masih kuat pengaruh hukum adatnya seperti Pengadilan Negeri Bali, Madura dan Sumatera Barat.

Berdasarkan latar belakang sebagaimana telah diuraikan di atas, maka dapat dirumuskan permasalahan sebagai berikut:

$\underline{\text { 1. Bagaimana penerapan Pasal 135a HIR oleh hakim }}$ dalam praktik penyelesaian sengketa perdata ke pengadilan di Pengadilan Negeri Bandung, Pengadilan Negeri Denpasar, Pengadilan Negeri Madura dan Pengadilan Negeri Padang?

2. Bagaimana akibat hukum dari tidak dipenuhinya ketentuan Pasal 135a HIR dalam penyelesaian sengketa perdata di Pengadilan Negeri?

\section{METODE}

Metode pendekatan yang digunakan adalah metode pendekatan yuridis normatif, yang meliputi penelitian inventarisasi hukum positif, penelitian terhadap asas-asas hukum dan penelitian hukum in concreto, penelitian sistematik hukum, penelitian sejarah hukum dan perbandingan hukum². Penelitian ini dengan cara meneliti data kepustakaan atau data sekunder yang diperoleh dari perpustakaan maupun instansi terkait yang berkompeten dengan penelitian ini. Sebagai penelitian hukum normatif dilakukan penelitian atas data sekunder berupa bahan-bahan hukum primer, bahan hukum sekunder dan bahan hukum tersier. ${ }^{3}$ Dalam penelitian ini akan diteliti tentang keberadaan putusan hakim perdamaian desa dalam penyelesaian sengketa perdata di pengadilan pada praktiknya dewasa ini. Spesifikasi Penelitian ini bersifat deskriptif analitis, yaitu membuat pencandraan secara istematis mengenai fakta-fakta ${ }^{4}$ termasuk didalamnya menggambarkan peraturan-peraturan yang berlaku ${ }^{5}$.

Penelitian ini dilakukan dalam dua tahap, yaitu penelitian kepustakaan (library research) dan pengumpulan data lapangan. Penelitian kepustakaan bertujuan untuk mengkaji, meneliti dan menelusuri data sekunder yang berupa bahan hukum primer, sekunder dan tersier. Selain studi kepustakaan juga dilakukan pengumpulan data-data lapangan (data primer) yang berkaitan dengan materi penelitian dan berfungsi sebagai pendukung data sekunder.

Teknik pengumpulan data yang akan digunakan dalam penelitian ini adalah studi kepustakaan yang berkaitan dengan permasalahan yang akan dibahas, dan untuk mengumpulkan data primer dilakukan dengan wawancara dengan nara sumber yang terpilih sesuai dengan kebutuhan penelitian. Terhadap data yang telah dikumpulkan baik itu data sekunder maupun data primer keseluruhannya akan dianalisis.

Metode analisis data yang digunakan dalam penelitian ini adalah normatif kualitatif, karena penelitian ini bertititik tolak dari peraturan perundangundangan yang ada sebagai norma hukum positif serta ditunjang oleh hasil pengumpulan data lapangan yang

\footnotetext{
2. Ronny Hanitijo Soemitro, Metodologi Penelitian Hukum dan Jurimetri, Ghalia Indonesia, Jakarta, 1990, hlm 9-10

3. Soerjono Soekanto dan Sri Mamudji, Penelitian Hukum Normatif suatu Tinjauan Singkat, Rajawali, Jakarta, 2006, hlm 13-14.

4. Op.cit. hlm 22

5. Sumadi, Metode Penelitian, CV Rajawali, Jakarta, 1988, hlm. 19
} 
dilakukan. Selanjutnya penalaran dilaksanakan dengan metode deduktif, kemudian dilakukan analisis secara yuridis kualitatif, yaitu data disusun secara sistematis untuk selanjutnya dianalisis secara kualitatif, yaitu hasil yang diperoleh diwujudkan dalam bentuk uraian. ${ }^{6}$

Penelitian dilakukan di Bandung, Bali, Madura dan Padang, antara lain di lokasi-lokasi sebagai berikut: a. Perpustakaan Fakultas Hukum Unpad, Perpustakaan

Program. Pascasarjana Unpad dan Perpustakaan Pusat Unpad.

b. Pengadilan Negeri Bandung, Pengadilan Negeri Bali, Pengadilan Negeri Madura dan Pengadilan Negeri Padang.

\section{HASIL DAN PEMBAHASAN}

\section{Kajian Teori tentang Putusan Hakim Perdamaian Desa}

Undang Undang Darurat Nomor 1 Tahun 1951 yang mengatur tentang tindakan-tindakan sementara untuk menyelenggarakan kesatuan susunan, kekuasaan dan acara pengadilan-pengadilan sipil, mengatur dalam Pasal 1 ayat (2) sub b yang menyatakan bahwa menghapuskan segala bentuk pengadilan termasuk Pengadilan Adat. Lebih lanjut dijelaskan dalam ayat (3) bahwa menghapuskan segala bentuk pengadilan termasuk pengadilan adat, tidaklah mengurangi hak kekuasaan yang telah diberikan kepada hakim-hakim perdamaian di desa-desa sebagaimana diatur dalam Pasal 135a $\mathrm{HIR} / 161 \mathrm{a} \mathrm{RBg}$.

Penyelesaian sengketa perdata melalui pengadilan bersumber pada Hukum Acara Perdata, dalam hal ini HIR untuk wilayah hukum Jawa dan Madura, dan RBg untuk wilayah luar Jawa dan Madura. Hukum acara dapat diartikan sebagai sekumpulan peraturan yang mengatur tentang prosedur penyelesaian sengketa perdata melalui pengadilan, yang sifatnya rigid dan memaksa sehingga tidak dapat disimpangi oleh pihak-pihak yang berperkara maupun oleh penegak hukum yang dalam hal ini hakim dan kuasa hukum.

Pasal 135a HIR mengatur tentang keberadaan dan peran hakim desa dalam penyelesaian sengketa perdata tertentu sebelum diselesaikan melalui pengadilan, yang secara lengkap berbunyi sebagai berikut:

(1) Jika tuntutan itu berhubungan dengan perkara pengadilan yang sudah diputus oleh hakim desa, maka pengadilan negeri harus mengetahui keputusan itu dan alasan-alasannya.

(2) Jika tuntutan itu berhubungan dengan perkara pengadilan yang belum diputuskan oleh hakim desa, sedang pengadilan negeri memandang ada manfaatnya perkara itu diputuskan oleh hakim desa, maka hal itu diberitahukan oleh hakim ketua kepada penggugat dengan memberikan selembar

6. Maria S.W. Sumardjono, Pedoman Pembuatan Usulan Penelitian, Yogyakarta,Fakultas Hukum Universitas Gadjah Mada, 1989, hlm. 24-25 surat keterangan. Perkara itu lantas diundurkan pemeriksaannya sampai hari persidangan yang ditentukan oleh ketua atas kekuatan jabatannya.

(3) Kalau hakim desa telah menjatuhkan keputusan, maka apabila penggugat berkehendak supaya pemeriksaan itu dilanjutkan, maka isi putusannya harus diberitahukan kepada pengadilan negeri bersama salinannya, kemudian perkara tersebut dilanjutkan pemeriksaannya.

(4) Jika dua bulan sesudah penggugat mengadukan perkaranya kepada hakim desa itu, hakim desa belum juga menjatuhkan keputusan, maka jika diminta oleh penggugat, perkara itu dapat diperiksa kembali oleh pengadilan.

(5) Kalau menurut pertimbangan hakim, penggugat tidak dapat dengan cukup memberi alasan yang dapat diterima, bahwa hakim desa tidak mau menjatuhkan putusan, maka hakim itu harus meyakini keadaan itu karena jabatan.

(6) Kalau ternyata bahwa penggugat tidak membawa perkara itu kepada hakim desa, maka gugatannya dipandang tidak diteruskan lagi.

Sebagaimana telah dikemukakan di atas, pengaturan tentang hukum acara perdata masih bersifat dualisme dengan adanya dua ketentuan yang mengatur dan berlaku di wilayah hukum yangtberbeda, yaitu HIR untuk daera Jawa dan Madura, sedangkan untuk wilayah luar jawa dan Madura berlaku RBg sebagai sumber hukum acaranya disamping sumber hukum acara lainnya.

Mengenai keberadaan putusan hakim perdamaian desa ini untuk Pengadilan di wilayah hukum luar Jawa dan Madura telah diatur dalam Pasal 143b dan Pasal 161a RBg. Pasal 143b RBg menyatakan bahwa: "Bila perkara yang diajukan (ke pengadilan) berkenaan dengan perkara yang telah diputus oleh hakim desa, penggugat memberitahukan isi dari keputusan tersebut pada surat gugatannya; bila mungkin, salinan keputusannya itu dilampirkan".

Kemudian dalam Pasal 161a dijelaskan secara lebih rinci bahwa:

(1) Bila perkara yang diajukan berkenaan dengan perkara yang telah diputuskan oleh pengadilan desa, ketua pengadilan harus memperhatikan putusan itu, teristimewa mengenai alasan-alasan yangdigunakan.

(2) Bila perkara itu berkenaan dengan hal yang tidak diberikan putusan oleh pengadilan desa, akan tetapi pengadilan menganggap perlu adanya putusan terlebih dahulu dari pengadilan desa, maka hal ini diberitahukan kepada penggugat dengan menyerahkan suatu bukti tertulis, dan siding perkara ditunda sampai pada sidang berikutnya yang ditetapkan karena jabatan oleh ketua pengadilan.

(3) Bila setelah pengadilan desa kemudian memberi putusan mengenai perkara itu dan penggugat menghendaki sidang perkara tetap dilanjutkan, maka 
putusan pengadilan desa itu harus diberitahukan kepada ketua pengadilan negeri, lebih baik dengan menyerahkan salinan dari putusan pengadilan desa tersebut, di mana setelah itu pengadilan melanjutkan sidangnya mengenai perkara tersebut.

(4) Bila pengadilan desa dalam waktu dua bulan setelah penggugat menyerahkan perkara kepadanya,belum juga mengadakan putusan, maka pengadilan negeri atas permohonan yang diajukan oleh penggugat, mulai kembali mengadakan sidang perkara tersebut.

(5) Bila penggugat tidak dapat meyakinkan hakim tentang penolakan oleh pengadilan desa untuk mengadakan putusan secara memuaskan, ketua pengadilan negeri dalam jabatannya akan memastikan hal itu.

(6) Bila temyata penggugat yang berkepentingan tidak mengajukan perkaranya kepada pengadilan desa, maka gugatannya dianggap telah gugur. (RO. 3a; IR. 135a; RBg. 143a.)

\section{Penerapan Pasal 135a HIR/161a RBg Dalam Penye- lesaian Sengketa Perdata di Pengadilan}

Sebagaimana telah diuraikan sebelumnya bahwa Pasal 135a HIR/ 161a RBg mengatur tentang keberadaan dan peran hakim desa dalam penyelesaian sengketa perdata tertentu sebelum diselesaikan melalui pengadilan. Dijelaskan bahwa jika ada gugatan masuk ke pengadilan dan tuntutan itu berhubungan dengan perkara pengadilan sedang pengadilan negeri memandang ada manfaatnya perkara itu diputuskan oleh hakim desa, dan hal tersebut belum diputuskan oleh hakim desa, maka diberitahukan oleh hakim ketua kepada penggugat dengan memberikan selembar surat keterangan agar perkera tersebut diperiksa terlebih dahulu dan diputus oleh hakim desa/hakim adat . Perkara itu lantas diundurkan pemeriksaannya sampai hari persidangan yang ditentukan oleh ketua atas kekuatan jabatannya (sampai ada putusan hakim desa).

Jika hakim desa telah menjatuhkan keputusan, makaapabila penggugatberkehendak supaya pemeriksaan itu dilanjutkan, maka isi putusannya harus diberitahukan kepada pengadilan negeri bersama salinannya, kemudian perkara tersebut dilanjutkan pemeriksaannya. Jika dua bulan sesudah penggugat mengadukan perkaranya kepada hakim desa itu, hakim desa belum juga menjatuhkan keputusan, maka jika diminta oleh penggugat, perkara itu diperiksa kembali oleh pengadilan. Kalau menurut pertimbangan hakim, penggugat tidak dapat dengan cukup memberi alasan yang dapat diterima, bahwa hakim desa tidak mau menjatuhkan putusan, maka hakim itu harus meyakini keadaan itu karena jabatan. Dan kalau ternyata bahwa penggugat tidak membawa perkara itu kepada hakim desa, maka gugatannya dipandang tidak diteruskan lagi, lihat Zulfa, 2010.

Dari hasil penelitian diperoleh data bahwa Pasal 135a HIR/161a RBg tidak pernah diperhatikan oleh hakim yang memeriksa perkara perdata di pengadilan, bahkan cenderung terlupakan keberadaan nya. Dalam praktik hakim tidak pernah menanyakan atau memperhatikan tentang putusan hakim perdamaian desa, hal ini setidaknya terjadi di Pengadilan Negeri Bandung, Pengadilan Negeri Padang, Pengadilan Negeri Sampang Madura dan Pengadilan Negeri Denpasar Bali.

Ketentuan Pasal 135a HIR/161a RBg tidak pernah diterapkan oleh hakim-hakim di Pengadilan Negeri Bandung. Hal ini disebabkan antara lain karena para hakim kurang memperhatikan keberadaan Pasal 135a $\mathrm{HIR} / 161 \mathrm{a} \mathrm{RBg}$, bahkan ada hakim yang tidak mengetahui tentang pasal tersebut. Dapat pula disebabkan karena ada anggapan bahwa pasal yang terkait dengan peradilan adat telah dinyatakan tidak berlaku, mengingat Undang Undang Darurat Nomor 1 Tahun 1951 telah mencabut keberadaan beberapa peradilan yang ada di Indonesia termasuk pengadilan adat.

Namun jika kita pelajari lebih lanjut UUDrt No. 1 tahun 1951, dengan penghapusan keberadaan pengadilan adat tidak termasuk menghapuskan keberadaan putusan hakim perdamaian desa. Karena dalam Pasal 1 ayat (3) dijelaskan bahwa penghapusan tersebut tidak mengurangi hak kekuasaan yang telah diberikan pada hakim-hakim perdamaian desa. Oleh karena itu Pasal 135a HIR/161a $\mathrm{RBg}$ yang mengatur tentang eksistensi putusan hakim perdamaian desa dalam pemeriksaan perkara perdata di pengadilan, belum dihapus dan masih dinyatakan berlaku. Dengan demikian alasan tidak pernah diterapkannya Pasal 135aHIR/161a RBg karena sudah tidak berlaku tidaklah beralasan.

Sementara hakim di Pengadilan Negeri Padang, Pengadilan Negeri Sampang Madura, dan Pengadilan Negeri Denpasar Bali, mengetahui keberadaan putusan hakim desa sebagaimana diatur dalam pasal-pasal dimaksud meskipun belum pernah menerapkannya dalam memeriksa dan memutus perkara perdata di pengadilan. Biasanya hasil putusan hakim desa tersebut disampaikan sebagai alat bukti berupa surat atau keterangan saksi yang diajukan dalam pembuktian oleh para pihak. Kemudian hakim mempertimbangkannya di dalam memutus perkara tersebut.

\section{Akibat Hukum Tidak Dipenuhinya Ketentuan Pasal 135a HIR/161a RBg Dalam Penyelesaian Sengketa Perdata Di Pengadilan}

Sebagaimana telah dijelaskan bahwa Pasal 135a HIR/161a RBg mengamanatkan bahwa untuk penyelesaian sengketa atau perkara-perkara yang dapat diselesaikan secara adat seperti misalnya pembagian penggunaan tanah dan sengketa adat lainnya, sebelum diajukan gugatan ke pengadilan, harus diselesaikan secara adat oleh hakim desa melalui putusan hakim perdamaian desa. Kemudian putusan hakim desanya disampaikan pada hakim (dilampirkan) pada saat mengajukan gugatan ke pengadilan.

Penjelasan atas Pasal 135a HIR/161a RBg 
menegaskan bahwa ketentuan ini diadakan dengan maksud agar Pengadilan Negeri jika melanjutkan pemeriksaan atas perkara dimaksud, hakim mempunyai pegangan dan pandangan bagaimana hakim desa menilai perkara tersebut dari sudut hukum adat. Bahkan lebih lanjut dikatakan bahwa jika penggugat tidak membawa perkara dimaksud itu kepada hakim desa setelah diperintahkan oleh ketua Pengadilan Negeri, maka gugatannya tidak akan diteruskan.

Lebih lanjut dijelaskan bahwa untuk sengketasengketa yang timbul karena perselisihan dan pertikaian di antara penduduk desa, seperti misalnya mengenai pertikaian tentang pembagian air, mengenai pemakaian tanah, penggembalaan ternak dan segala sesuatu yang mengenai adat kebiasaan di desa dan peri kehidupan sehari-hari di dalam lingkungan desa itu; harus diselesaikan dulu pada tingkat pengadilan desa melalui hakim desa yang berlandaskan pada penyelesaian secara damai dengan putusan hakim perdamaian desa. Apabila masih belum dapat diselesaikan secara tuntas, maka dapat diajukan ke Pengadilan Negeri untuk diperiksa kembali.

Kepentingan adanya putusan hakim perdamaian desa untuk kasus-kasus tertentu, dimaksudkan untuk menselaras kan pemikiran dan pertimbangan hukum hakim yang memeriksa perkara tersebut di Pengadilan Negeri dengan hakim desa yang telah memutus sebelumnya, sehingga pemeriksaan perkara dapat lebih cepat karena langsung terfokus pada pokok perkara dengan melanjutkan hasil pemeriksaan hakim desa yang juga dijadikan pertimbangan hukum oleh hakim dalam memutus perkara dimaksud. Pada gilirannya akan membantu tercapainya asas peradilan cepat, sederhana dan biaya ringan, lihat pula Mc. Donagh, 1998.

Pengadilan Desa berbeda dengan Pengadilan Adat, pada pengadilan desa tidak ada penegasan hukum materiil yang harus diberlakukan (diterapkan). Di samping itu daerah kerjanya terbatas hanya meliputi satu desa atau satu dusun saja dalam persekutuan hukum yang bersifat territorial dan hanya meliputi kerabat suku tertentu saja dalam persekutuan hukum yang bersifat kekerabatan. ${ }^{7}$

Hakim pada peradilan desa memberlakukan hukum adat baik material maupun formal, tidak terikat pada sesuatu peraturan perundang-undangan dalam melaksanakan peradilan. Cara melaksanakan peradilan adalah dengan musyawarah dan mufakat atas dasar kekeluargaan dan kerukunan kekerabatan atau kerukunan ketetanggaan. Persidangan yang diadakan bukan untuk mewujudkan suatu keputusan melainkan untuk mencari jalan penyelesaian yang sepakat, seia-sekata karena saling pengertian. Apabila para pihak dapat menerima hasil penyelesaian yang disetujui bersama, maka itulah putusannya.

\footnotetext{
7. Herowati Poesoko, Paradigma Pengadilan Adat Dalam Sistem Peradilan perdata Di Indonesia, Makalah disampaikan pada Semiloka Eksistensi Lembaga Peradilan Adat Dalam Prespektif Hukum Acara Perdata Nasional, Fakultas Hukum Universitas Andalas, 22-24 Mei 2013.
}

Sebagaimana diketahui bahwa pada asasnya penyelesaian perkara di pengadilan harus diselesaikan dalam waktu yang tidak lama dengan prosedur yang sederhana sehingga biaya perkara yang dikeluarkan akan lebih sedikit. Hal ini sesuai dengan apa yang diharapkan oleh asas peradilan yang cepat, sederhana dan biaya ringan sebagaimana diamanatkan oleh Undang Undang No. 48 Tahun 2009 Tentang Kekuasaan Kehakiman.

Pasal 2 ayat (4) Undang Undang Nomor 48 Tahun 2009 tentang Kekuasaan Kehakiman menyebutkan bahwa: "peradilan dilakukan dengan cepat, sederhana dan biaya ringan". Lebih lanjut dikatakan dalam Pasal 4 ayat (2) bahwa: "Pengadilan membantu pencari keadilan dan berusaha mengatasi segala hambatan dan rintangan untuk dapat tercapainya peradilan yang sederhana, cepat, dan biaya ringan. Dalam penjelasan dikatakan bahwa yang dimaksud dengan "sederhana" adalah pemeriksaan dan penyelesaian perkara dilakukan dengan cara efisien dan efektif, sedangkan yang dimaksud dengan "biaya ringan" adalah biaya perkara yang dapat dijangkau oleh masyarakat.

Penerapan Pasal 135a HIR/161a RBg dalam penyelesaian sengketa perdata di pengadilan dimaksudkan untuk menselaras kan pemikiran dan pertimbangan hukum hakim yang memeriksa perkara tersebut di Pengadilan Negeri dengan hakim desa yang telah memutus sebelumnya, sehingga pemeriksaan perkara dapat lebih cepat karena langsung terfokus pada pokok perkara. Di samping pemeriksaan perkara akan lebih cepat, juga lebih sederhana dan dengan sendirinya akan mengurangi biaya perkara. Hal ini sejalan dengan tujuan asas peradilan cepat, sederhana dan biaya ringan.

Berpijak dari uraian Pasal 135a HIR/161a RBg sebagaimana telah diuraikan di atas, yang menarik perhatian adalah apa yang dinyatakan dalam ayat (2) bahwa jika Ketua Pengadilan Negeri menganggap perlu bahwa perkara itu diselesaikan dahulu oleh hakim desa, maka pemeriksaan di muka pengadilan negeri diundurkan untuk memberi kesempatan dilakukan pemeriksa an oleh hakim desa.

Ketentuan ini diadakan dengan maksud jika perkara itu akan diteruskan agar pengadilan negeri mempunyai pegangan dan pandangan bagaimana hakim desa melihat perkara itu dari sudut hukum adat. Keputusan hakim desa itu dianggap demikian penting sehingga bila penggugat bersangkutan ternyata tidak membawa perkara itu kepada hakim desa setelah diperintahkan oleh Ketua Pengadilan Negeri, maka pemeriksaan perkara itu dipandang tidak akan dilanjutkan.

\section{SIMPULAN}

Penerapan Pasal 135a HIR/161a RBg oleh hakim dalam praktik penyelesaian sengketa perdata di Pengadilan Negeri Bandung menurut keterangan nara sumber tidak 
pernah dilakukan setidaknya dalam masa tugas nara sumber, hal ini disebabkan hakim tidak memperhatikan keberadaan pasal tersebut. Sementara di Pengadilan Negeri Padang, Pengadilan Negeri Sampang Madura, dan Pengadilan Negeri Denpasar Bali, meskipun hakim mengetahui tentang keberadaan putusan hakim perdamaian desa sebagaimana diatur dalam pasal tersebut, namun belum pernah menerapkannya dalam praktik penyelesaian sengketa perdata.

Berdasarkan penjelasan Pasal 135a HIR/161a RBG, bahwa keputusan hakim desa itu demikian penting sehingga apabila penggugat belum menyelesaikan perkara tersebut ke hakim desa padahal hakim memandang perlu untuk diperiksa lebih dahulu oleh hakim desa, maka pemeriksaan perkara diundur untuk memberikan kesempatan pemeriksaan oleh hakim desa. Apabila yang bersangkutan ternyata tidak membawa perkara itu kepada hakim desa setelah diperintahkan oleh Ketua Pengadilan Negeri, maka akan berakibat hukum pemeriksaan perkara itu tidak akan dilanjutkan.

\section{DAFTAR PUSTAKA}

Maria S.W. 1989. Sumardjono, Pedoman Pembuatan Usulan Penelitian, Yogyakarta, Fakultas Hukum Universitas Gadjah Mada.
McDonagh, R. 1989. Benchmarking of existing national legal e-business practices:Country Report of Ireland.

Mertokusumo, S. 2006. Hukum Acara Perdata Indonesia, edisi keenam, Yogyakarta: Liberty.

Poesoko, H. 2013 Paradigma Pengadilan Adat Dalam Sistem Peradilan perdata Di Indonesia, Makalah disampaikan pada Semiloka Eksistensi Lembaga Peradilan Adat Dalam Prespektif Hukum Acara Perdata Nasional, Fakultas Hukum Universitas Andalas, 22-24 .

Sumadi. 1988. Metode Penelitian, Jakarta: CV Rajawali.

Soemitro. R.H. 1990. Metodologi Penelitian Hukum dan Jurimetri, Jakarta: Ghalia Indonesia.

Soekanto, S. dan Mamudji, S. 2006. Penelitian Hukum Normatif suatu Tinjauan Singkat, Jakarta: Rajawali

Tresna, R. 1989. Komentar HIR, Pradnya Paramita, Bandung.

Zulfa, E.A. 2010. Keadilan Restoratif Dan Revitalisasi Lembaga Adat Di Indonesia, Jurnal Kriminologi Indonesia, Vol. 6 No. II Agustus 